potential routes for a multisynaptic itch reflex from the substantia to the nucleus of the trigeminal nerve in the medulla.

The transmission of nerve impulses that give rise to a spinal reflex may be blocked by local anaesthesia. Our patients have not complained of itch since we added a small amount of bupivacaine to our intrathecal heroin preparation $(1.0 \mathrm{mg}$ freeze-dried heroin and $0.25 \mathrm{mg}$ bupivacaine plain in $1.0 \mathrm{ml}$ saline; $\mathrm{pH} 6.183$, specific gravity 1.004 at $37^{\circ} \mathrm{C}$ ).

On this evidence an enkephalinergic reflex may well provide a credible alternative to histamine release as an explanation for facial itching associated with intraspinal administration of opiates. The reflex might be relayed at a central level by a medullary itch centre having a close functional link with the spinal nucleus of the trigeminal nerve.

We thank Dr J A Savin, Royal Infirmary, Edinburgh, and Dr I Parkin, Medical School, Birmingham, for key references.

1 Bernstein JE, Grinzi RA. Butorphanol-induced pruritus antagonized by naloxone. F Am Acad Dermatol 1981 ;5:227-8.

2 Bernstein JE, Swift R. Relief of intractable pruritus with naloxone. Arch Dermatol 1979;115:1366-7.

${ }^{3}$ Summerfield JA. Naloxone modulates the perception of itch in man Br f Clin Pharmacol 1980;10:180-2.

- Koenigstein H. Experimental study of itch stimuli in animals. Archives of Dermatology and Syphilology 1948;57:828-49.

5 Andreev V, Petkov I. Skin manifestations associated with tumours of the brain. Br $\mathcal{F}$ Dermatol 1975;92:675-8.

(Accepted 8 fanuary 1982)

Bromsgrove General Hospital, Bromsgrove, Worcestershire

PETER V SCOTT, MB, FFARCS, consultant anaesthetist

H B J FISCHER, MB, FFARCS, consultant anaesthetist

\section{Acute pancreatitis: a complication of beta-blockade}

Severe hypertriglyceridaemia is a well-recognised cause of acute pancreatitis. Increases in serum triglyceride concentration have been reported after beta-adrenergic blockade. ${ }^{1-3}$ We describe a patient in whom beta-blockade was associated with severe hypertriglyceridaemia and acute pancreatitis and in whom beta-blocking agents were shown to impair serum triglyceride clearance.

\section{Case report}

A 64-year-old man with a 20-year history of peripheral and coronary artery disease and gout was admitted as an emergency case because of prolonged angina at rest. He was not diabetic and drank alcohol only occasionally. He had been prescribed metoprolol $100 \mathrm{mg}$ twice daily but on admission had a sinus tachycardia ( 130 beats $/ \mathrm{min}$ ). Propranolol $5 \mathrm{mg}$ intravenously relieved his angina and reduced the heart rate, and atenolol $100 \mathrm{mg}$ daily by mouth was started.

On the fifth hospital day the laboratory was unable to perform routine biochemical tests because of pronounced turbidity of the serum. Concentration of serum triglycerides was $56.0 \mathrm{mmol} / 1(4956 \mathrm{mg} / 100 \mathrm{ml}$ ) (normal $<1.7$ $\mathrm{mmol} / 1(150 \mathrm{mg} / 100 \mathrm{ml}))$ and of serum cholesterol $18.0 \mathrm{mmol} / 1(695 \mathrm{mg} / 100$ $\mathrm{ml}$ ) (normal $<7.0 \mathrm{mmol} / 1(270 \mathrm{mg} / 100 \mathrm{ml})$ ). Type $\mathrm{V}$ hyperlipoproteinaemia was confirmed by ultracentrifugation. Before admission serum triglyceride values had been raised during metoprolol treatment, but had not exceeded $13 \mathrm{mmol} / 1(1150 \mathrm{mg} / 100 \mathrm{ml})$. Next day the patient developed back pain and two days later severe central abdominal pain and hypotension. Serum amylase activity was $4460 \mathrm{U} / 1$, confirming acute pancreatitis. There was no clinical evidence of intestinal obstruction, and abdominal radiography and ultrasound examination showed no free gas or gall stones. He was managed conservatively with intravenous fluids and nasogastric aspiration. As he improved a diet containing $20 \mathrm{~g}$ fat was introduced. An attempt to withdraw beta-blocking drugs failed because of recurring angina and tachycardia. Despite this, with the low-fat diet the concentration of serum triglycerides was down to $3.7 \mathrm{mmol} / \mathrm{l}(327 \mathrm{mg} / 100 \mathrm{ml})$ and cholesterol to $7.0 \mathrm{mmol} / \mathrm{l}$ $(270 \mathrm{mg} / 100 \mathrm{ml})$ within two weeks.

The patient was subsequently admitted to the metabolic ward and, while continuing a $20 \mathrm{~g}$ fat diet, the effect of atenolol $100 \mathrm{mg}$ daily and metoprolol $100 \mathrm{mg}$ twice daily on the clearance of intravenously administered $10 \%$ Intralipid ( $1 \mathrm{ml} / \mathrm{kg}$ ) was studied. In the absence of beta-blockade triglyceride clearance was normal, but was almost halved by both beta-blockers (figure).

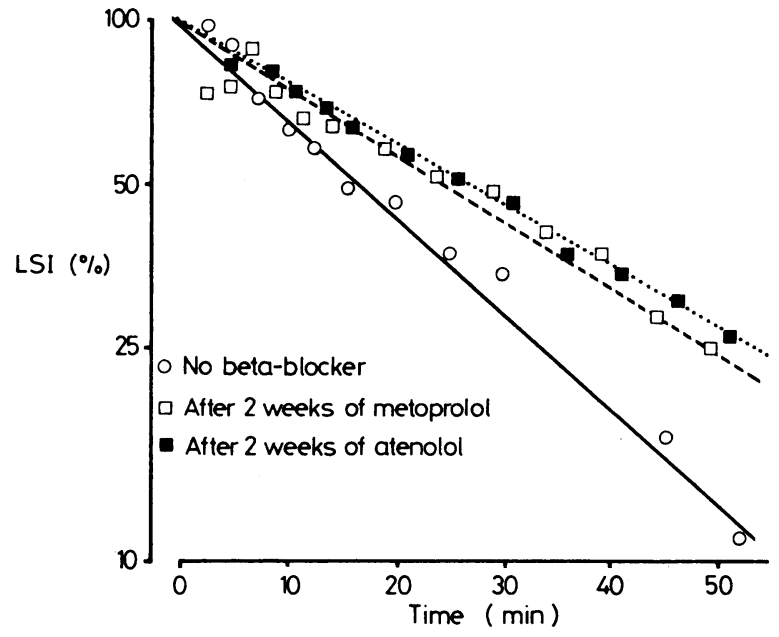

Effect of beta-adrenergic-blocking drugs on clearance of $10 \%$ Intralipid administered intravenously. $O=$ No beta-blocker (halflife $\left(t \frac{1}{2}\right) 16.5 \mathrm{~min}$; elimination rate constant $\left.\left(k_{2}\right)-4.2 \% / \mathrm{min}\right)$. $\square=$ After two weeks of metoprolol $100 \mathrm{mg}$ twice daily (t 124.5 $\left.\min ; \mathbf{k}_{2}-2 \cdot 8 \% / \mathrm{min}\right) . \quad=$ After two weeks of atenolol $100 \mathrm{mg}$ daily ( $\left.t \frac{1}{2} 27.0 \mathrm{~min} ; k_{2}-2.6 \% / \mathrm{min}\right) . \%$ LSI =Percentage theoretical light-scattering index at zero time.

\section{Comment}

The rise in concentration of serum free fatty acids which occurs with stress may result in increased hepatic production of triglycerides. Such stress-induced hypertriglyceridaemia is not, however, enough to cause acute pancreatitis and, in any case, beta-blockade reduces serum free fatty acid concentrations ${ }^{2}$ and would thus limit hypertriglyceridaemia from this cause.

The rise in the concentration of serum triglycerides in our patient was apparently due to impaired catabolism, since beta-blockade was associated with impaired triglyceride clearance. This most probably reflected reduced endothelial lipoprotein lipase (EC 3.1.1.3) activity. Lipoprotein lipase removes triglycerides from both chylomicrons and very low density lipoproteins. It has been suggested that alphaadrenergic stimulation, unopposed by beta-adrenergic stimulation, reduces the activity of this enzyme ${ }^{3}$ and that this may be the mechanism by which beta-blocking drugs, in particular those without betaagonist (intrinsic sympathetic) activity, permit impairment of triglyceride clearance. In stress, when catecholamine secretion is increased, such an effect would be heightened. We suggest that the stress of acute myocardial ischaemia in the presence of effective betablockade so impaired triglyceride clearance in our patient that serum triglyceride concentrations sufficient to provoke acute pancreatitis were achieved.

Doctors prescribing beta-blockers for acute coronary insufficiency should be alert to the possibility of inducing severe hypertriglyceridaemia in susceptible patients and its dangerous complication.

We thank Professor S W Stanbury for permission to study his patient.

1 England JDF, Hua ASP, Shaw J. $\beta$-adrenoreceptor blocking agents and lipid metabolism. Clin Sci Mol Med 1978;55,suppl 4:323-4.

2 Day JL, Simpson N, Metcalfe J, Page RL. Metabolic consequences of atenolol and propranolol in treatment of essential hypertension. $\mathrm{Br} \mathrm{Med} \mathcal{F}$ $1979 ; \mathrm{i}: 77-80$

3 Day JL. Alterations in plasma lipids during beta adrenergic blockade. In : Noseda G, et al, eds. Lipoproteins and coronary atherosclerosis. Elsevier/ North Holland Biomedical Press. In press.

Lewis B. The hyperlipidaemias: clinical and laboratory practice. London Blackwell Scientific Publications, 1976.

5 Havel RL, Goldstein JL, Brown MS. Lipoproteins and lipid transport. In Bondy PK, Rosenberg LE, eds. Metabolic control and disease. 8th ed. Philadelphia: W B Saunders, 1980:393-494.

(Accepted 14 December 1981)

University Department of Medicine, Manchester Royal Infirmary, Manchester M13 9WL

P N DURRINGTON, MD, MRCP, lecturer in medicine and honorary senior registrar

S A CAIRNS, MD, MRCP, senior registrar 